\title{
COMMENTS
}

\section{An Adjudicative Role for Federal Magistrates in Civil Cases}

In order to relieve part of the work load of federal district courts, Congress enacted the Federal Magistrates Act of $1968,{ }^{1}$ creating a new class of federal judicial officers to replace the existing system of masters and commissioners. Because masters and commissioners normally served only temporarily or part time and because of the manner in which they were compensated, Congress was reluctant to invest either office with new substantive powers. Masters were paid a "reasonable fee" for services rendered, a practice that encouraged the master to deliberately create unnecessary work in order to increase his fee. ${ }^{2}$ Commissioners were often paid by the piece-for example, receiving compensation if they issued an arrest warrant but not if they refused. ${ }^{3}$ In addition, many masters and commissioners were practicing members of the bar, raising problems of possible conflicts of interest and often resulting in serious delays, since many officers gave their private practice precedence over their judicial duties. ${ }^{4}$ To eliminate these problems, the

128 U.S.C. $\S \S 631$ et seq. (1970).

2 This problem long plagued the master system. See 6 Works of JEREMY Benthan 43 (J. Bowring ed. 1843); 1 W. Holdsworth, A History of ENGLIsH LAw, 441-42 (4th ed. 1927). It was dealt with in part by giving trial courts wide discretion in setting fee awards and by appellate review of those awards. Cf. Newton v. Consolidated Gas, 259 U.S. 101 (1922). Nevertheless, recent objections to reference as involving unreasonable expense seem predicated in part on the abuses to which the "reasonable fee" system is prone, cf. La Buy v. Howes Leather Co., 352 U.S. 249 (1957); Adventures in Good Eating v. Best Places to Eat, Inc., 131 F.2d 809 (7th Cir. 1942).

3 See Act of June 25, 1948, ch. 646, 62 Stat. 916. Although there is uncertainty as to whether the statute in fact made payment contingent upon issuance of a warrant, most commissioners believed that it did. See Hearings Before the Subcomm. on Improvements in Judicial Machinery of the Senate Comm. on the Judiciary on S. 3475, 89th Cong., 2d Sess. 468, 474 (1967) [hereinafter cited as Senate Hearings].

4 For a discussion of delay problems, see A. Vanderbilt, Cases and Other Materials on Modern Procedure and Judicial Administration 1240-41 (1952); Kaufman, Masters in the Federal Courts: Rule 53, 58 Colum. L. REv. 452 (1958). See also La Buy v. Howes Leather Co., 352 U.S. 249 (1957); United States v. Kirkpatrick, 186 F.2d 393 (3d Cir. 1951); Adventures in Good Eating v. Best Places to Eat, Inc., 131 F.2d 809 (7th Cir. 1942). The Act deals with this problem by providing that a full time magistrate may not practice law, 28 U.S.C. $\$ 632$ (a) (1970), and by generally providing that no magistrate may engage in any business inconsistent with the proper performance of his judicial duties, id. \$§ 632(a), (b). In reference to the conflicts of interest proßlem, see United States v. O'Connor, 291 
1968 Act gave to magistrates fixed terms of office at fixed salaries. ${ }^{5}$ By these provisions, Congress attempted to attract competent, highly qualified persons to the new positions ${ }^{6}$ and thus to justify allowing masters to exercise powers more extensive than those previously allowed commissioners and masters. ${ }^{7}$

In the 1968 Act, Congress vested magistrates with jurisdiction over petty criminal offenses ${ }^{8}$ and, prior to the Act's passage, Congress's attention seems to have focused largely on this new grant of power. ${ }^{9}$ Nonetheless, the Act makes clear that Congress had another purposeto enable magistrates to relieve district courts of some part of their civil, as well as their criminal, work load. ${ }^{10}$ Magistrates' duties explicitly include, but are not limited to, service as special masters pursuant to Federal Rule of Civil Procedure 53, assistance to district judges in pretrial and discovery proceedings in both civil and criminal actions, and preliminary review of habeas corpus petitions. ${ }^{11}$ More importantly

F.2d 520 (2d Cir. 1961); In re Volland, 69 F.2d 475 (7th Cir. 1934); Senate Hearings, supra note 3, at 5-9, 277-78; cf. Tumey v. Ohio, 273 U.S. 510 (1927).

5 The Act explicitly expresses a preference for full time magistrates, 28 U.S.C. \& 633(a) (3) (1970), who are to be appointed for a term of eight years, id. § 631(e), with a fixed salary not to exceed 75 percent of the salary of a district court judge, id. § 634(a). This salary may not be reduced during the magistrate's term in office, id. § 634(b). Part time magistrates are appointed for a term of four years, id. § 634(a). Neither full time nor part time magistrates may be removed from office except for "incompetency, misconduct, neglect of duty, or physical or mental disability" as found by a majority of the judges of the district, $i d .631(h)$.

- For example, between 20 percent and 30 percent of commissioners were not even lawyers. Senate Hearings, supra note 3 , at 164, 461. The fact that a single judge could appoint masters and commissioners also gave rise to fears of patronage and nepotism. Cf. id. at 164. The Magistrates Act requires a magistrate to be appointed by a majority of the judges of the district. 28 U.S.C. \$ 631(a) disqualifies any person related by blood or marriage to a judge of the appointing court, $i d . \$ 631(b)(4)$, and requires the magistrate to be a qualified member of the bar of the highest court in the state in which he is to serve unless both the appointing court and the Judicial Conference find that no qualified member of the bar is available, $i d$. § 631(b).

7 See Senate Hearings, supra note 3, at 9-17; Hearings before Subcomm. No. 4 of the Comm. on the Judiciary on S. 549 et al., 90th Cong., 2d Sess. 60-67 (1968) [hereinafter cited as House Hearings]. Control of discovery and pre-trial hearings was the original concept of the usefulness of the federal magistrate in civil hearings. See Senate Hearings, supra note 3, at 23, 239; Kaufman, supra note 4. Questions have been raised about the actual economizing effects of the use of magistrates in pre-trial hearings. See TPO, Inc. v. McMillen, 460 F.2d 613 (8th Cir. 1957). This comment, however, proposes use of the magistrate to hear the entire cause and is, therefore, not affected by such considerations. The district courts would be left free to use the magistrates in whatever pre-trial roles seem best under the circumstances of the particular cases.

828 U.S.C. $636($ a) (1970).

9 Cf. Senate Hearings, supra note 3, at 4-9; House Hearings, supra note 7, at 60-67.

1028 U.S.C. 636(b) (1970); see Senate Hearings, supra note 3, at 11; House Hearings, supra note 7 , at $66-67,157$.

1128 U.S.C. 636(b) (1970). 
perhaps, the Act provides that a majority of judges in each district may, by rule, assign to magistrates "such additional duties as are not inconsistent with the Constitution and laws of the United States."12

The Magistrates Act thus offers a means of alleviating, in some measure, the pressures and delays that overcrowded dockets now impose on the district courts. In particular, the district courts may, under the Act, allow magistrates to make final decisions in civil cases, subject only to a "clearly erroneous" standard of review by the district court. In a number of recent cases, however, the courts have expressed either grave doubts about or direct disapproval of the exercise by magistrates of adjudicative powers in civil cases. ${ }^{13}$ These opinions have equated the civil adjudicative powers of magistrates with those of masters acting under Federal Rules of Civil Procedure 53, ${ }^{14}$ which restricts references to masters, except in matters of account, to cases in which "some exceptional condition requires it." 15 Since the master's conclusions of law are given no weight, ${ }^{10}$ use of a master produces piecemeal litigation-one adjudicator for fact, another for law.

This comment argues that these restrictions on magistrates' powers are not constitutionally required. Rather, they are based on a longstanding reaction to the possibilities of abuse in the former system of masters and the consequent recognition that reference to masters was normally undesirable. The Magistrates Act, however, was intended to eliminate these possibilities of abuse. There is long-standing precedent for reference, when both parties have consented, of entire civil cases for decision as to both law and fact. A policy encouraging consensual reference under the new magistrate system is both permissible and desirable as a means of reducing congestion in the district courts. Use of the proposed adjudicative powers of federal magistrates would provide a needed middle ground between arbitration and full trial in the district court.

$12 \mathrm{Id}$.

13 See TPO, Inc. v. McMillen, 460 F.2d 348 (7th Cir. 1972); Devcon Corp. v. Woodhill Chemical Sales Corp., 455 F.2d 830 (1st Cir. 1972), cert. denied, 409 U.S. 845 (1972); Rainha v. Cassidy, 454 F.2d 207 (1st Cir. 1972). See also Batiste v. Furnco Constr. Corp., 350 F. Supp. 10 (N.D. Ill. 1972). But see Henderson v. Brierly, 468 F.2d 1193 (3d Cir. 1972); Givens v. W. T. Grant Co., 457 F.2d 612 (2d Cir. 1972), vacated, 409 U.S. 56 (1972).

14 Direct reliance is placed in the principal case, TPO, Inc. v. McMillen, 460 F.2d 348, 360 (7th Cir. 1972), on the rules developed to deal with the problems of references under the master system.

15 FED. R. Crv. P. 53(b).

$16 \mathrm{Id}$. 53(e). Findings of fact are reviewed on a "clearly erroneous" standard in nonjury cases, id. 53(e)(2), and may be introduced as evidence in jury cases, id. 53(e)(3). The only exception to these review standards occurs when the parties stipulate that the master's findings of fact shall be final, in which case, "only questions of law arising upon the report shall thereafter be considered." Id. 54(e)(4). 
In TPO, Inc. $v$. McMillen, ${ }^{17}$ the most comprehensive of the recent opinions limiting the civil powers of magistrates, defendant's motion for summary judgment had been referred to a magistrate. Plaintiffs consented to the reference, but the defendants objected. Without discussing the relevance of consent the Seventh Circuit stated broadly that: "[M]agistrates have no power to decide motions to dismiss or motions for summary judgment, both of which involve ultimate decision making .... [T] ]he order of reference here was lacking in power and 'amounted to little less than an abdication of the judicial function depriving the parties of a trial before the court on the basic issues involved in the litigation." "18 The TPO decision borrowed the "abdication of the judicial function" concept from a masters case, ${ }^{19}$ thus importing into the developing law of magistrates concepts and restrictions developed in reference to special masters. The court justified this importation by reference to the statement in the Magistrates Act that magistrates could act as special masters subject to the restrictions of Rule $53 .{ }^{20}$

The leading case on Rule 53 is La Buy v. Howes Leather Co. ${ }^{21}$ The district court, over the objections of both parties, had referred a complex antitrust case to a master. At the time of reference the judge had already heard and decided requests for discovery and admissions and motions to dismiss and for summary judgment. The court of appeals granted mandamus vacating the order of reference; the Supreme Court affirmed. As the Supreme Court noted, the judge's "knowledge of the cases at the time of the references, together with his long experience in the antitrust field, points to the conclusion that he could dispose of the litigation with greater dispatch than anyone else."22 The Court's decision did not rest, however, upon either the lack of consent or an interest in judicial economy. Instead, the Court stated that references amount "to little less than an abdication of the judicial function" and that 'the practice of making references 'does not commend itself' and '. . . should seldom be made, and if at all only when unusual circumstances exist." "23

17460 F.2d 348 (7th Gir. 1972).

$18 \mathrm{Id}$. at 359, quoting La Buy v. Howes Leather Co., 352 U.S. 249, 256 (1957).

10 La Buy v. Howes Leather Co., 352 U.S. 249 (1957).

2028 U.S.C. $\$ 636(\mathrm{~b})(1)(1970)$.

21352 U.S. 249 (1957).

$22 I d$. at 256.

23 Id. at 258, citing In re Irving-Austin Bldg. Corp., 100 F.2d 574, 577 (7th Cir. 1938). 
The principle of $L a$ Buy does not reach the new federal magistrates. The Court's statements were instead a reaction against having cases tried "before a temporary substitute appointed on an ad hoc basis and ordinarily not experienced in judicial work."24 The Court quoted at length a statement by Chief Justice Vanderbilt that sums up the then dominant attitudes about masters: "There is no more effective way of putting a case to sleep for an indefinite period than to permit it to go to a reference with a busy lawyer as a referee. Only a drastic administrative rule, rigidly enforced, strictly limiting the matters in which a reference may be had ... will put to rout this inveterate enemy of dispatch in the trial of cases." 25 Since the problems of delay, ignorance, and conflict of interest were present in all references at that time, a logical solution was the blanket restriction on the use of masters.

This implementation of a policy decision against the use of masters has been interpreted, however, as a policy decision against references to any non-Article III tribunal and thus has come to be applied to the magistrate system. The disapproval of masters even as a matter of policy is, however, a relatively recent development. The prior common law of references suggests uses of the magistrate system far beyond the limited role it is presently accorded.

\section{II}

In the early nineteenth century, the Supreme Court explicitly approved the use of masters in complex cases. ${ }^{26}$ The Court also recognized a distinction in the standard of review between cases in which the parties had not consented to the reference and those cases in which there was " a reference of the [entire] cause by consent." It was recognized that, when both parties have consented to reference, "[the] report is to be considered as an award obligatory on all the parties, unless set aside for some of those causes which are admitted to vitiate an award."27

24 Id. at 259.

$25 \mathrm{Id}$. at 253 n.5.

26 See Heckers v. Fowler, 69 U.S. 123 (1864); Heirs of P.F. Dubourg de St. Colombe v. United States, 32 U.S. (7 Pet.) 624 (1833); cf. Thornton v. Carson, 11 U.S. (7 Cranch) 596 (1813).

27 Field v. Holland, 10 U.S. (6 Cranch) 8, 21 (1810). These cases did not treat the seventh amendment problems of reference, but in United States v. Rathbone, $27 \mathrm{~F}$. Cas. 711 (No. 16,121) (C.C.S.D.N.Y. 1828), the circuit court in holding that a reference without consent was violative of the seventh amendment, stated: "Admitting the court had no power to order the cause referred, yet there can be no doubt this could be done by the consent of the parties." Id. at 711. See also, Ex Parte Peterson, 253 U.S. 300 (1920); Graffis v. Woodward, 96 F.2d 329 (7th Cir. 1938), cert. denied, 305 U.S. 631 (1938). But cf. In 
The principal question during this period was not what cases might be referred, but rather what the standard of review should be when the master's report came before the trial court. This question was directly presented in Kimberly $v . A r m s,{ }^{28}$ in which Justice Field set out a rule of review based on consent to reference:

[The trial court] cannot, of its own motion, or upon the request of one party, abdicate its duty to determine by its own judgment the controversy presented, and devolve that duty upon any of its officers. But when the parties consent to the reference of a case to a master or other officer to hear and decide all the issues therein, and report his findings, both of fact and of law, and such reference is entered as a rule of the court, the master is clothed with very different powers from those which he exercises upon ordinary references, without such consent; and his determinations are not subject to be set aside and disregarded at the mere discretion of the court. ... [The master's] findings, like those of an independent tribunal, are to be taken as presumptively correct, subject, indeed, to be reviewed under the reservation contained in the consent and order of the court, when there has been manifest error in the consideration given to the evidence, or in the application of the law, but not otherwise. ${ }^{29}$

The Kimberly rule was approved in subsequent cases, ${ }^{30}$ but the Court ignored the element of consent in several opinions that held that where the trial court concurred in the master's findings, the findings were "to be taken as presumptively correct, and unless some obvious error has intervened in the application of the law, or some serious or important mistake has been made in the consideration of the evidence, the decree should be permitted to stand."31

The early Rules of Equity governing masters made no reference to consent or to restrictions on the use of masters. ${ }^{32}$ In 1912, without any clear indication of reasons, the Equity Rules on masters were amended to state that "[s]ave in matters of account, a reference to a master shall be the exception, not the rule, and shall be made only upon a showing that some exceptional condition requires it." 33 In Los

re Narragansett Pier Amusement Corp. 224 F.2d 231 (Ist Cir. 1955), cert. denied, 350 U.S. 862 (1955); Vermeule v. Reilly, 196 F. 226 (S.D.N.Y. 1912).

28129 U.S. 512 (1888).

$29 \mathrm{Id}$. at 524.

30 E.g., Davis v. Schwartz, 155 U.S. 631, 637 (1895).

31 Crawford v. Neal, 144 U.S. 585, 596 (1892). See also Furrer v. Ferris, 145 U.S. 132 (1892). These cases relied on a pre-Kimberly line of similar rulings, e.g., Tilghman v. Proctor, 125 U.S. 136 (1887); Medsker v. Bonebrake, 108 U.S. 66 (1883).

32 Equity R. 73-83, 42 U.S. (1 How.) 1xiv-1xvii (1842).

33 Equity R. 59, 226 U.S. 666 (1912). 
Angeles Brush Corp. v. Jones, ${ }^{34}$ the Supreme Court construed this provision to forbid blanket referrals of patent cases. The construction was justified not on constitutional grounds, but rather because it spared patent litigants the expense of reference. The reference involved in the case was held to be justified because calendar congestion was preventing consideration of criminal cases by the trial courts. The language used, however, indicated that the limitation of reference to "exceptional circumstances" was to be strictly construed. ${ }^{35}$ In spite of the "exceptional circumstances" rule, the Kimberly concept of the effect of consent continued to be relevant to the standard of review of a master's report. ${ }^{36}$

The first serious reduction in the weight given the master's report came in Ex Parte Peterson, ${ }^{37}$ in which the Court approved the use of an auditor to define the issues before a jury trial. The Court's dicta implied, however, that an auditor's report could in no case be more than prima facie evidence, a means of defining the issues and shifting the burdens of persuasion. Later interpretations of Peterson have focused on this dicta, ignoring the fact that the auditor in that case was appointed without consent of the defendant. ${ }^{38}$

The 1932 revision of the Equity Rules discarded the Kimberly consent rule. Rule $61 \frac{1}{2}$ provided that in all references, whether compulsory or "by consent of parties where consent is necessary," all findings of law and fact were to be subject to the same standard of review; they were to be treated as presumptively correct, subject to reversal if the court "is fully satisfied that error has been committed."39 As pointed out in Roosevelt $v$. Missouri State Life Insurance Co., ${ }^{40}$ the new rule meant that the parties could no longer consent, as they had in Kimberly, to review on a "substantial evidence" standard. The new rule continued to allow the parties to consent to review by the same standard governing review of arbitrators' decisions; ${ }^{41}$ but since arbitrators' decisions are

34272 U.S. 701 (1927).

35 This was a blanket reduction in the number of cases that could be referred, and as such it was taken to apply without reference to consent of the parties.

36 See Connor v. United States, 214 F. 522 (9th Gir. 1914); cf. Denver v. Denver Union Water Co., 246 U.S. 178 (1918), where the Court, in holding that the report of a master on a consensual reference was advisory only, relied on the fact that the consent agreement and the order of reference provided that the master was to report his findings of fact and of law "for the advisement of the court." Id. at 180-81. The Court thus implicitly reaffirmed the principle of Kimberley that consent could determine the standard of review.

37253 U.S. 300 (1920).

38 E.g., La Buy v. Howes Leather Co., 252 U.S. 249, 256 (1957).

39 Equity R. 61골, 286 U.S. 571 (1932).

4070 F.2d 939 (8th Gir. 1934). See also Lone Star Gas Co. v. Forth Worth, 93 F.2d 584 (5th Cir. 1937), cert. denied, 304 U.S. 562 (1938).

41 Equity R. 611 286 U.S. 571 (1932). 
essentially unreviewable, ${ }^{42}$ this provision simply left the parties with a choice between no review and a mere presumption of correctness. The rules also continued to require that reference could be had only "in exceptional circumstances." 43

Rule 53 of the Federal Rules of Civil Procedure, adopted in 1938, consolidated the previous Equity Rules on masters. The new rule stated that "[ $t]$ he effect of a master's report is the same whether or not the parties have consented to the reference; but, when the parties stipulate that a master's findings of fact shall be final, only questions of law arising upon the report shall thereafter be considered." 44 In nonjury cases, where the parties did not stipulate finality for findings of fact, they were to be reviewed on a "clearly erroneous" standard; 45 in jury cases the findings were to be introducible as evidence. ${ }^{46}$ No provision was made for giving weight to the master's findings of law.

The comments to the new rule made no mention of the restriction of the report to findings of fact, erroneously stating that the rule was substantially identical to the old Equity Rules. ${ }^{47}$ With the elimination, however, of the master's power to make findings of law, parties seeking an adjudication of their dispute in a single proceeding were faced with a choice between consent to an independent arbitrator, who would not use court procedures and whose decision would be for all practical purposes unreviewable in court, and a full scale trial in the district court. It had thus become clearly impossible to consent to a full adjudication in an adjunct of the district court where issues of law and fact could be determined under court procedures and any serious defects in the result could be appealed.

The present Rule 53 is substantially the same as that adopted in 1938, but the intervening years have seen increasing disapproval of the practice of reference. The Seventh Cicuit, for example, in Adventures in Good Eating v. Best Places to Eat, Inc., ${ }^{48}$ denounced reference because masters "are expensive and time-consuming. The delay in some instances is unbelievably long. Likewise, the increase in cost is heavy. For nearly a century, litigants and members of the bar have been crying against this avoidable burden of costs and this inexcusable delay." 49

42 See text and notes at notes 53-63 infra.

43 Equity R. 59, 226 U.S. 666 (1912), was left unchanged by the 1932 revisions.

44 Fed. R. Crv. P. 53(e)(4), 308 U.S. 731 (1939).

45 FED. R. Crv. P. 53(e)(2), 308 U.S. 730-31 (1939).

46 FED. R. Crv. P. 53(e)(3), 308 U.S. 731 (1939).

47 5A J. Moore, Federal Practice 953.01 [6] (2d ed. 1971).

48131 F.2d 809 ('7th Cir. 1942).

$49 \mathrm{Id}$. at 814. Similarly, United States v. Kirkpatrick, 186 F.2d 393 (3d Cir. 1951), interpreting Admixalty Rule 43 as equivalent to Rule 53, disapproved reference to an 
In 1957 the Supreme Court stated its serious disapproval of the master system in La Buy v. Howes Leather Co. ${ }^{50}$ discussed above, using the "abdication of the judicial function" language to express the policy disapproval of the shortcomings of the master system.

\section{III}

The Magistrates Act eliminated the problems that had given rise to the policy against references. ${ }^{51}$ As the opinion in TPO demonstrates, however, courts continue to view reference as "an abdication of the judicial function." The language used by the courts implies a constitutional limitation on the ability of courts to make even consensual references. This concept of constitutional restrictions conflicts with long-standing approval in several areas of the law of federal court enforcement of decisions by non-Article III federal tribunals when the parties had consented to the tribunal.

Arbitration has long been recognized as a means of "private" dispute settlement that removes disputes from the district courts. ${ }^{52} \mathrm{~A}$ contractual agreement to submit disputes to arbitration determines the scope of authority of the arbitrator in the same way that Kimberly allowed the order of reference to define the master's authority. ${ }^{53}$ The primary distinction between arbitration and consensual reference to a magistrate is that an arbitration award can be reversed only on very limited grounds, ${ }^{54}$ such as evident bias on the part of the arbitrator, ${ }^{55}$

admiralty commissioner on the ground that it "would be to impose upon a group of litigants against their will the expense and delay of unnecessary reference." Id. at 397. Both Adventures in Good Eating v. Best Places to Eat, Inc., 131 F.2d 809 (7th Cir. 1942), and United States v. Kirkpatrick, supra, involved reference over the objection of one of the parties, but only Kirpatrick made any special mention of this fact.

50352 U.S. 249 (1957). This opinion has been only slightly mitigated by a few subsequent circuit court decisions approving use of masters in limited pre-trial settings. See Wilver v. Fischer, 387 F.2d 66 (10th Cir. 1967); McGraw-Edison Co. v. Central Transformer Corp., 308 F.2d 70 (8th Cir. 1962); Illinois Gas \& Elec. Co., 245 F.2d 613 (8th Cir. 1957), cert. denied, 355 U.S. 871 (1957).

51 See text and notes at notes 1-7 supra.

52 See Butler Products Co. v. Unistrut Corp., 367 F.2d 733 (7th Cir. 1966); Burchell v. Marsh, 58 U.S. 344 (1854). See generally W. Sturges, Commirrcial Arbitrations and AWARDS (1930).

53 See 9 U.S.C. $\S 2$ (1970); Marceron v. Chevy Chase Servs., Inc., 258 F.2d 155 (D.C. Cir. 1958); Wright Lumber Co. v. Herron, 199 F.2d 446 (10th Cir. 1952).

54 Under the Federal Arbitration Act, an award may be vacated only when procured by corruption, fraud, or undue means; where the arbitrators were obviously prejudiced; where the arbitrators engaged in misconduct prejudicial to the rights of the parties; or where the arbitrators exceeded or imperfectly executed their powers so that a proper award was not made. 9 U.S.C. \& 10 (1970).

55 See Commonwealth Coatings Corp. v. Continental Gas Co., 393 U.S. I45 (1968); American Guarantee Trust v. Caldwell, 72 F.2d 209 (9th Cir. 1934). 
the entry of an award that is in manifest disregard of the law or which compels disobedience to a law or an established public policy, ${ }^{56}$ or evidence that the arbitrator went beyond the scope of his authority. ${ }^{57}$ Arbitrators need not adhere to court procedure, ${ }^{58}$ the rules of evidence, ${ }^{69}$ nor the Federal Rules of Civil Procedure, ${ }^{60}$ nor need they render any opinion explaining their decision. ${ }^{\text {} 1}$ A factor distinguishing arbitration from district court and magistrates' proceedings, although not from masters' proceedings, is that arbitrators must be compensated by the parties- $a$ factor that often makes arbitration a very costly undertaking. It has often been held that public policy favors reference to arbitration; ${ }^{62}$ if this is so, it is difficult to understand how reference to a magistrate can be considered, in all cases, "an abdication of the decision making authority."

Deprecation of the magistrate in civil cases is also inconsistent with their extensive use in criminal cases. Although Felix Frankfurter argued that trial by magistrate of petty offenses was constitutional regardless of consent, ${ }^{63}$ in the Federal Magistrates Act Congress required that the defendant consent to trial by magistrate. ${ }^{64}$ The petty offense jurisdiction was justified in the legislative debates on several grounds. Among these was tradition; ${ }^{05}$ the law has always recognized the pro-

56 See Wilko v. Swan, 346 U.S. 427 (1953); San Martine Compania De Navegacion, S.A. v. Saguenay Terminals, Ltd., 293 F.2d 796 (9th Cir. 1961).

57 See J.P. Greathouse Steel Erectors, Inc. v. Blount Bros. Const. Co., 374 F.2d 324 (D.C. Cir. 1967), cert. denied, 373 U.S. 949 (1967); Orion Shipping \& Trading Co. v. Eastern States Petroleum Corp. of Panama, S.A., 312 F.2d 299 (2d Cir. 1963), cert. denied, 373 U.S. 949 (1963).

58 See Compania Panemena Maritima San Gerassimo, S.A. v. J.E. Hurley Lumber Co., 244 F.2d 286 (2d Cir. 1957); American Almond Products Co. v. Consolidated Pecan Sales Co., 144 F.2d 448 (2d Cir. 1944).

50 See Petroleum Separating Co. v. Interamerican Ref. Corp., 296 F.2d 124 (2d Cir. 1961).

60 See Foremost Yarn Mills, Inc. v. Rose Mills, Inc., 25 F.R.D. 9 (E.D. Pa. 1960).

61 See Montana Power Co. v. Federal Power Comm'n, 445 F.2d 739 (D.C. Cir. 1970), cert. denied, 400 U.S. 1013 (1971); Hale v. Friedman, 281 F.2d 635 (D.C. Cir. 1960). But see Sobel v. Hertz, Warner \& Co., 338 F. Supp. 287 (S.D.N.Y. 1971) (arbitrator must give sufficient reasons to show that decision was within statute controlling arbitration decision).

02 See Butler Products Co. v. Unistrut Corp., 367 F.2d 733 (7th Cir. 1966); Metro Indus. Painting Corp. v. Terminal Constr. Co., 287 F.2d 382 (2d Cir. 1961), cert. denied, 368 U.S. 817 (1961); Robert Lawrence Co. v. Devonshire Fabrics, Inc., 271 F.2d 402 (2d Cir. 1959), cert. dismissed, 364 U.S. 801 (1961).

03 Frankfurter \& Corcoran, Petty Federal Offenses and the Constitutional Guarantee of Trial by Jury, 39 HARv. L. REv. 917 (1926). See also Doub \& Kestenbaum, Federal Magistrates for the Trial of Petty Offenses: Need and Constitutionality, 107 U. PA. L. REv. 443 (1959).

o4 28 U.S.C. $\S 636$ (1970), by incorporating the provisions of 18 U.S.C. $\S 3401$ (1970), requires the consent of the defendant.

05 See Senate Hearings, supra note 3, at 276. 
priety of trying petty offenses to a magistrate, preserving appeal to an Article III tribunal. A more persuasive argument was based on Congress's Article I power to create tribunals for certain cases over which the Supreme Court does not have original jurisdiction. ${ }^{68}$ This power has been used, for example, to require state courts to try certain federal penal offenses. ${ }^{67}$ Consensual reference of civil or criminal cases to a federal magistrate is less a denial of Article III protections than is a mandatory relegation of cases to state courts. While the federal magistrate, unlike the state court, is exercising the "judicial power" of the United States, any requirement that the magistrate himself be an Article III judge would be gratuitous in light of the consent given by the parties. The right to trial in the district court is preserved; the parties are simply given the option of appearing before a different tribunal. If this justification supports use of magistrates in crimina] cases, then a fortiori it must support their use in civil cases.

\section{IV}

A system of consensual reference to federal magistrates is constitutionally permissible and finds support in early master doctrine. Three questions remain, however, with regard to the desirability and feasibility of wide use of federal magistrates to reduce the district court civil case load. First, would widespread reference result in judicial economies? Second, is consensual reference authorized by the present Magistrates Act or is new legislation necessary? Third, assuming that consensual references are both permissible and practically desirable, what inducements can or should be offered to encourage consent?

\section{A. Judicial Economy}

Cases such as $T P O^{68}$ and $L a B u y^{68}$ argued that decision by the district judge "could dispose of the litigation with greater dispatch and less effort than anyone else."70 This was true on the facts of those cases, since the action in each case had been split into two parts: facts were tried before the magistrate and law before the court. A reference of the entire case would, however, allow all the economies of the use of one informed tribunal. Use of a system of consensual reference would pro-

66 See id. at $246-55$.

67 See Testa v. Katt, 330 U.S. 386 (1947); Senate Hearings, supra note 3, at 255-56. See generally Note, Utilization of State Courts to Enforce Federal Penal and Criminal Statutes: Developments in Judicial Federalism, 60 HARv. L. REv. 966 (1947); cf. Blackmon v. Lee, 12 F.R.D. 411 (D.D.C. 1952).

68 TPO, Inc. v. McMillen, 460 F.2d 348 (7th Cir. 1972).

69 La Buy v. Howes Leather Co., 352 U.S. 249 (1957).

$70 \mathrm{Id}$. at 256. 
duce three sorts of benefits. To the extent that the less difficult cases are channelled to the magistrate, district judges will be freed to deal more effectively with the more difficult and important cases. Second, if the magistrates' dockets are kept uncongested, the parties, and society as a whole, will receive the benefits of rapid adjudication and more careful consideration of cases by both tribunals. ${ }^{71}$ Third, a magistrate may be hired for one term only, eliminating presently existing congestion without the need to engage tenured judges who may be unnecessary after the congestion has been relieved.

Two caveats are in order with regard to the possible economies of a system of consensual reference. First, a reduction in direct outlays for litigation or in the costs occasioned by delay will reduce the costs of some aspects of litigation without reducing the stakes in the suit. The parties will respond to this decrease by spending more on other aspects of litigation, such as discovery, and it is impossible to determine a priori whether there will be a net reduction in the total cost of legal dispute resolution. ${ }^{72}$ Second, an increase in the speed with which matters go to trial will increase the effective stakes in the controversy, because the time during which no interest accrues on the alleged damages is decreased. Other things being equal, an increase in the stakes will reduce the incentive to settle the controversy before trial and more cases will proceed to trial. This will in turn increase the demand for magistrates and offset part or all of the initial reduction in congestion. ${ }^{73}$

Assuming that the use of magistrates will create trial economies, there remains the possibility that magistrates' decisions will be appealed more often, offsetting the gains. But this is unlikely. Only a small percentage of the cases decided in district courts are appealed. ${ }^{74}$ Insofar as the magistrate's decision is reviewed on the same standard as is

71 The magistrates would begin with a completely empty docket. If trial by magistrate was considered the precise equivalent of trial by the district court and consent was induced solely by speed, the demand for trial by magistrate would soon equalize the congestion in district and magistrate courts. In reality, however, parties can be expected to perceive magistrate courts as inferior, either in training or merely in symbolic value. The absolute demand for magistrates will therefore be less than for district courts. This smaller demand will be offset by the advantages of speed at a point somewhere between no delay and the district court congestion. One additional means of insuring uncongested magistrates courts would be for the district judges to be selective in the cases they approved for referral.

72 See Posner, An Economic Approach to Legal Procedure and Judicial Administration, 2 J. Legar Studies 399 (1973); cf. Hazard, Rationing Justice, 8 J. LAW \& Econ. 1 (1965);

Landes, An Economic Analysis of the Courts, 14 J. Law \& Econ. 61 (1971).

73 See sources cited note 72 supra.

74 See annual Report of the Director of the Administrative Office of the United States Courts 101-03, 119 (1971). 
presently applied to district court decisions, and assuming that costs of appeal are similar and reversal no more likely, a similar percentage of appeals will be taken from magistrates' decisions. This would result in a load reduction to the district courts similar to that presently provided to the courts of appeal by the district courts. Nor is it necessary that cases tried before a magistrate be appealable to both the district court and the circuit court of appeals. Appeals from certain non-Article III tribunals are presently taken directly to the circuit courts. $^{75}$ Article III leaves to Congress complete discretion over the jurisdiction of the lower courts and the routing of appeals among them, so that appeals from magistrates' decision might also be limited to the district courts with no review in the circuit courts.

\section{B. Legality under the Act}

The Magistrates Act permits any references "not inconsistent with the Constitution and laws of the United States," "76 thereby allowing reference whenever the parties consent. The subcommittee memorandum that accompanied the Act stated:

Since full-time magistrates under the new system are supposed to spend all their time on their official duties, it is appropriate to allow the district court to make whatever use of their services as it sees fit, in addition to the functions that the statute assigns them .... The use of magistrates for duties that do not require the employment of an Article III judge, or in cases in which the parties consent to the use of a magistrate, may do much to increase the efficiency of the Federal courts. ${ }^{77}$

During congressional consideration of the Act, the suggestion that magistrates might perform a wide range of duties received favorable comment. ${ }^{78}$ The question of consent as a basis for granting adjudicatory powers in civil cases was largely ignored, but when it did arise it was also commented upon favorably. ${ }^{79}$ Thus, if the parties consent, it seems

75 E.g., appeals from NLRB enforcement orders taken under \& 10(f) of the L.M.R.A., 29 U.S.C. $\$ 160(f)(1970)$, and appeals from decisions of the Environmental Protection Agency under $\S 307(\mathrm{~b})(1)$ of the AIR Pollution CoNTrol ACT, 42 U.S.G. $\S 1857(\mathrm{~h})(5)(\mathrm{b})(\mathrm{I})$ (1970).

7628 U.S.C. \& $636(\mathrm{~b})(1970)$.

77 Senate Hearings, supra note 3 , at 14 (emphasis added).

78 E.g., id. at 234; House Hearings, supra note 7, at 73. These comments often referred to the pre-trial duties of magistrates, a focus that is probably attributable to the virtual disregard of the possibility of consensual reference in civil cases rather than to any intent to limit the powers of magistrates.

79 "I believe that lawyers in New York City (the area with which I am most familiar) would consent to trials before United States magistrates in a fair number of civil cases. ... The result of permitting magistrates to try civil cases would probably be a substantial 
clear that the Magistrates Act authorizes reference in all cases according to rules set out by the district courts.

\section{Incentives to Reference}

The major advantage of a reference would be the speed with which a case would be considered and a decision rendered. ${ }^{80}$ When both parties desire a speedy resolution, there would be no problems in obtaining consent. Plaintiffs often desire speed to reduce attorney's costs, to avoid deterioration of the evidence, and to minimize the losses resulting from interest being paid only from the date of the judgment. But the defendant may often prefer delay, since each of these factors weakens the plaintiff's case and decreases the plaintiff's minimum settlement demand. It is, therefore, necessary to devise inducements to encourage the defendant to consent to a magistrate. ${ }^{81}$

First, it may be possible to remove some of the existing incentives for delay. For example, interest on a claim is, at present, calculated only from the time of the judgment, making it a reasonable economic precaution for the defendant to delay as long as possible. This incentive could be eliminated by awarding interest from the day of filing. ${ }^{82}$

Second, incentives to use reference to magistrates could be created through a system of filing fees. Adjudication of claims by the federal courts is at present substantially subsidized by the federal government, because filing fees cover only a small portion of court costs. Such a subsidy of civil claims is justifiable only insofar as the adjudication of claims between parties serves to generate rules beneficial to society in general. A requirement that parties using the comparatively more expensive district court system bear part of the differential cost would be justifiable if district court decisions retained their quality despite diversion of cases to magistrates where magistrates' decisions are not treated as precedent or if magistrates decisions are treated as precedent but regarded as not significantly less valuable than district court decisions. Lower costs would be assessed to the parties using the less expensive magistrate system. A flat filing fee differential would, in all likelihood, force some smaller claims into magistrate courts. Assuming that parties' preference for district courts is based on a belief in a higher

lightening of the docket, an important consideration in view of current concern with the volume of work in the federal courts." Senate Hearings, supra note 3, at 235 (remarks of Mr. Irving Younger).

80 See note 73 supra.

81 See sources cited at note 74 supra.

82 In addition, if the interest rate used by the court was slightly higher than the market rate, there would be a positive inducement to the defendant for speed and thus to reference. 
quality of legal, rather than factual, decisions, a flat filing fee differential would also induce cases involving easily resolved legal questions, and thus of low precedential importance, into the magistrate's courts. ${ }^{83}$

A third incentive to reference can be produced by the appointment of masters skilled in particular nonlegal areas. For example, parties to a patent case involving complex scientific questions of fact but relatively straightforward questions of law are very likely to prefer a scientifically trained and legally competent magistrate to a legally superior but scientifically incompetent district judge. As the legal issues in such a case increase relative to the scientific issues, the incentive to reference will decrease, thus selecting the cases of lesser precedential value for reference.

Since the need to offer inducements arises because speed has a positive value to plaintiffs and a negative value to defendants, it is possible to induce defendants to consent to reference by allowing plaintiffs to "pay" to defendants some of the value conferred upon plaintiffs by the increase in speed. While there might be objections to a plan proposing direct cash payments to "purchase" consent, the same effect can be achieved through other means. One device would be to allow plaintiff and defendant to agree, in the consent to reference, on a maximum damage award. This would directly confer value on the defendant by reducing the stakes that the defendant stands to lose; since the maximum could be set at any sum, the defendant could be "paid" any price agreed on through the device. This "purchase" of consent would occur whenever the plaintiff's perceived benefits from speed are greater than defendant's perceived benefits from delay, and the gap between plaintiff's minimum settlement demand and defendant's maximum settlement offer is greater than the "price" plaintiff pays to obtain reference.

Speed, interest from the date of claim, filing fee differentials, and "purchase" of consent are all means of inducing consent. Insofar as the effects of widespread use of consensual reference will not be fully clear until after the system has been tested, those inducements that involve least change in the present system are likely to meet with least resistance in the legal community. It is suggested, therefore, that a system of consensual reference be attempted first with speed and "purchase" as the only inducements; interest from the date of claim might be added after the system has been tested or as part of a general reform of rules on interest. Differential filing fees, however, should not be employed until after the system of consensual reference has proven itself.

83 The problem of possible discrimination against indigents could be dealt with by a fee waiver method similar to that presently in use. 


\section{Conclusion}

Recent cases concerning federal magistrates have strongly disapproved any exercise by the magistrates of civil adjudicative powers. This disapproval is closely linked with the rules developed to prevent abuses of the earlier system of special masters. These recent cases, however, ignore the element of consent to reference as a validating factor. In early decisions on masters, it was recognized that entire cases could be referred to masters for decision if the parties consented. This practice in no way conflicts with Article III of the Constitution. Insofar as the Magistrates Act removes many of the problems that made reference to a master undesirable, a return to a system of consensual reference could provide a means of reducing the work load of and congestion in the district courts. Under such a system, those parties using the federal forum merely as a springboard to settlement or for resolution of relatively simple problems could be induced to consent to a reference, leaving the district courts free to deal with the more difficult and precedent setting cases. 